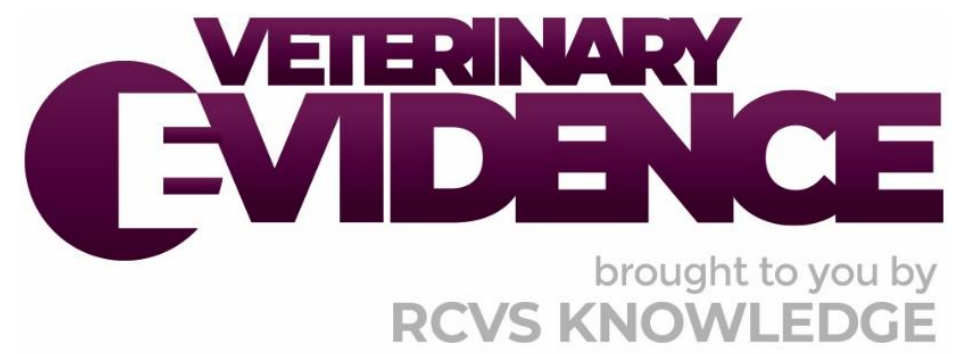

\title{
Does surgical or medical management of extrahepatic portosystemic shunts in dogs carry a better prognosis for the resolution and reduction of neurological dysfunction?
}

\section{A Knowledge Summary by}

Julia Smachlo DVM MPH ${ }^{1 *}$

Wanda J Gordon-Evans DVM PhD DACVS DACVSMR ${ }^{1}$

\footnotetext{
${ }^{1}$ University of Minnesota College of Veterinary Medicine, 1365 Gortner Ave, St Paul, MN 55108, USA *Corresponding Author (smach001@umn.edu)
}

ISSN: 2396-9776

Published: 09 Feb 2022

in: Veterinary Evidence Vol 7, Issue 1

DOI: https://doi.org/10.18849/ve.v7i1.360

Reviewed by: Marios Charalambous (DVM PgC PgD CSci PhD Dipl. ACVIM [Neurology] FHEA MRCVS) and Hélène Vandenberghe (DVM DipECVN MRCVS)

Next Review Date: 28 Feb 2023 


\section{KNOWLEDGE SUMMARY}

\section{PICO question}

In dogs with congenital extrahepatic portosystemic shunts that are treated with surgical attenuation what is the persistency, frequency, severity and outcome of neurological signs when compared to dogs that are treated medically?

\section{Clinical bottom line}

\section{Category of research question}

\section{Prognosis}

\section{The number and type of study designs reviewed}

Ten papers were critically reviewed

\section{Strength of evidence}

Weak

\section{Outcomes reported}

For short-term success, owners reported an overall decrease in neurological signs associated with neurological dysfunction and an increase in quality of life after the initiation of either medical management or surgical management. Surgical management has a weak association with higher mortality or severe neurological signs in the immediate postoperative period

\section{Conclusion}

It is challenging to make a direct comparison between medical and surgical management but, overall, both strategies seemed to decrease neurological signs in the short term. There was a lack of evidence and available data about the efficacy of each for long-term control of neurological signs

\section{How to apply this evidence in practice}

The application of evidence into practice should take into account multiple factors, not limited to: individual clinical expertise, patient's circumstances and owners' values, country, location or clinic where you work, the individual case in front of you, the availability of therapies and resources.

Knowledge Summaries are a resource to help reinforce or inform decision making. They do not override the responsibility or judgement of the practitioner to do what is best for the animal in their care.

\section{Clinical scenario}

Preanaesthetic bloodwork was consistent with a portosystemic shunt in a 6 month old male Yorkshire Terrier puppy. Subsequent bile acid stimulation tests were also consistent with a shunt. The owner would like to know what the prognosis and outcome of neurological dysfunction is assuming her dog has an extrahepatic portosystemic shunt (EHPSS) before she commits to referral for surgical attenuation compared to managing her dog medically without surgical intervention.

\section{The evidence}

All of the studies analysed were retrospective studies, which have a higher level of bias than prospective studies. Furthermore, four of the retrospective studies were descriptive case series studies, which also have low levels of evidence. The remaining six studies were retrospective cohort studies, which have better 
evidence than descriptive studies, but overall still have low levels of evidence. Additionally, the majority of the studies did not evaluate the persistence, frequency and severity of neurological dysfunction following either surgery or medical management as their primary problem or did not make distinctions between intrahepatic and extrahepatic shunts, which made drawing conclusions from the data difficult. There was also very limited evidence on the efficacy of solely medical management for extrahepatic portosystemic shunts in dogs. Studies that directly compared the impact of surgical and medical management on portosystemic shunts did not differentiate between intrahepatic and extrahepatic shunts so they could not be made relevant to the question and were excluded.

\section{Summary of the evidence}

Favier et al. (2020)

\begin{tabular}{|c|c|}
\hline Population: & $\begin{array}{l}\text { Dogs with a single congenital portosystemic shunt (CPSS) confirmed } \\
\text { by CT and / or ultrasound who did not have surgical intervention and } \\
\text { received non-surgical treatment that were referred to Utrecht } \\
\text { University, the Netherlands, between September } 2003 \text { and February } \\
2015 .\end{array}$ \\
\hline Sample size: & 78 dogs. \\
\hline Intervention details: & $\begin{array}{l}\text { - Case records were reviewed to identify dogs that received } \\
\text { medical management for a single CPSS. } \\
48 \text { of these dogs had an extrahepatic CPSS and } 29 \text { had an } \\
\text { intrahepatic CPSS. In one dog, CPSS was diagnosed, but the } \\
\text { location of the shunt could not be established. } \\
\text { - Records for } 65 \text { dogs who were medically managed were } \\
\text { divided in two treatment groups. One group }(n=27) \text { was } \\
\text { managed with restricted protein diet and lactulose for one } \\
\text { month or until death. The other group }(n=38) \text { was } \\
\text { medically managed with only a restricted protein diet for } 1 \\
\text { month or until death. }\end{array}$ \\
\hline Study design: & Single centre retrospective cohort study. \\
\hline Outcome studied: & $\begin{array}{l}\text { - Quality of life as assessed by the owner. } \\
\text { - Occurrence and frequency of clinical signs as assessed by the } \\
\text { owner. } \\
\text { - Survival time. } \\
\text { - Presumed cause of death. }\end{array}$ \\
\hline $\begin{array}{l}\text { Main findings: } \\
\text { (relevant to PICO question): }\end{array}$ & $\begin{array}{l}\text { - Estimated median survival time for dogs with an } \\
\text { extrahepatic portosystemic shunts (EHPSS) was } 41.5 \text { months } \\
\text { ( } 95 \% \mathrm{Cl} 35.2-47.8) \text {. } \\
20 \text { EHPSS dog owners responded to the follow-up } \\
\text { questionnaire ( } 17 \text { intrahepatic portosystemic shunt dog } \\
\text { owners responded). } 11 \text { of these dogs received the adjusted } \\
\text { diet and nine received the adjusted diet with lactulose. } \\
\text { - Of the } 37 \text { questionnaire responses, the CPSS scores were } \\
\text { significantly lower ( } p=0.01 \text { ) with medical management } \\
\text { (median } 18 \text { ) than before treatment (median } 35 \text { ). } \\
\text { Of the } 37 \text { questionnaire responses, quality of life scores } \\
\text { significantly increased ( } p<0.0001 \text { ) with medical management } \\
\text { (median 4) than before treatment (median } 2 \text { ). }\end{array}$ \\
\hline
\end{tabular}




\begin{tabular}{|c|c|}
\hline Limitations: & $\begin{array}{l}\text { - Retrospective study is at risk for more bias than a } \\
\text { - Suspective study. } \\
\text { - } \quad \text { Reliance on owner recollection and follow-up, which } \\
\text { increase the risk of recall bias and there was loss of follow- } \\
\text { up with only } 37 / 56 \text { ( } 66 \%) \text { of the owners responding to the } \\
\text { follow-up questionnaire. } \\
\text { - Owners elected euthanasia if quality of life declined, which } \\
\text { could alter the accuracy of the estimated median survival } \\
\text { time. }\end{array}$ \\
\hline
\end{tabular}

\begin{tabular}{|c|c|}
\hline \multicolumn{2}{|l|}{ Fryer et al. (2011) } \\
\hline Population: & $\begin{array}{l}\text { Dogs with a single extrahepatic portosystemic shunt (EHPSS) } \\
\text { confirmed by abdominal ultrasounds, nuclear scintigraphy, or } \\
\text { clinically relevant bile acids or ammonia concentration, and } \\
\text { underwent surgery application of an ameroid constrictor at Texas } \\
\text { A\&M University's Veterinary Medical Teaching Hospital, Texas, USA, } \\
\text { between January } 2003 \text { and November } 2010 \text {. }\end{array}$ \\
\hline Sample size: & 126 dogs. \\
\hline Intervention details: & $\begin{array}{l}\text { - Electronic medical records were searched to find eligible } \\
\text { dogs for the study. } \\
\text { - Surgical management of the EHPSS with an ameroid } \\
\text { constrictor. } \\
\text { Dogs were divided into two groups, } 42 \text { dogs who were } \\
\text { treated with levetiracetam (LEV) at a median of } 60 \\
\mathrm{mg} / \mathrm{kg} / \text { day at least } 1 \text { day before EHPSS ligation, and } 84 \text { dogs } \\
\text { that had no anticonvulsant drugs before EHPSS ligation. }\end{array}$ \\
\hline Study design: & Single centre retrospective cohort study. \\
\hline Outcome studied: & $\begin{array}{l}\text { - Proportion of dogs with neurological dysfunction. } \\
\text { - Blood ammonia concentrations. } \\
\text { - Postoperative complications. }\end{array}$ \\
\hline $\begin{array}{l}\text { Main findings: } \\
\text { (relevant to PICO question): }\end{array}$ & $\begin{array}{l}\text { - } 4 / 84 \text { dogs }(5 \%) \text { in the group that did not receive LEV had } \\
\text { postoperative seizures. } \\
\text { - } \text { Risk of seizures was significantly }(p<0.0002)<1 \text { for the dogs } \\
\text { that received LEV with Bayesian statistics. } \\
\text { - } 4 / 126 \text { dogs }(3 \%) \text { postoperatively had generalised motor } \\
\text { seizures and did not survive to discharge. }\end{array}$ \\
\hline Limitations: & $\begin{array}{l}\text { - Retrospective study is at risk for more bias than a } \\
\text { prospective study. } \\
\text { - No follow-up past the hospital discharge with the dogs to } \\
\text { assess additional postoperative neurological dysfunction. }\end{array}$ \\
\hline
\end{tabular}

\begin{tabular}{|l|l|}
\hline Harvey \& Erb (1998) \\
\hline \multicolumn{1}{|l|}{ Population: } & $\begin{array}{l}\text { Dogs with a congenital extrahepatic portosystemic shunt (CEPSS) } \\
\text { that presented to the Veterinary Medical Teaching Hospital of the } \\
\text { College of Veterinary Medicine at Cornell University, USA, between } \\
1985 \text { and } 1996 .\end{array}$ \\
\hline
\end{tabular}




\begin{tabular}{|c|c|}
\hline Sample size: & 56 dogs. \\
\hline Intervention details: & $\begin{array}{l}\text { - Medical records were reviewed to identify dogs with complete } \\
\text { records that underwent surgery for a CEPSS. } \\
\text { - Surgical management of the CEPSS with complete or partial } \\
\text { ligation. }\end{array}$ \\
\hline Study design: & Single centre retrospective case series. \\
\hline Outcome studied: & $\begin{array}{l}\text { Preoperative signs of hepatic encephalopathy including: } \\
\text { transient blindness, circling, seizures, head pressing, and } \\
\text { disorientation. } \\
\text { - Ability to completely ligate the single shunting vessel in non- } \\
\text { encephalopathic dogs compared to encephalopathic dogs. } \\
\text { - Follow-up of neurological signs in non-encephalopathic dogs. }\end{array}$ \\
\hline $\begin{array}{l}\text { Main findings: } \\
\text { (relevant to PICO question): }\end{array}$ & $\begin{array}{l}\text { - } 12 / 56 \text { dogs ( } 21 \% \text { ) displayed no preoperative signs of } \\
\text { encephalopathy and } 44 / 56 \text { dogs ( } 79 \% \text { ) displayed preoperative } \\
\text { signs of encephalopathy. } \\
\text { - } 1-10 \text { year follow-up period of } 8 / 12 \text { non-encephalopathic dogs } \\
\text { reported the development of no neurological signs as reported } \\
\text { by the owners. }\end{array}$ \\
\hline Limitations: & $\begin{array}{l}\text { - Retrospective study is at risk for more bias than a prospective } \\
\text { study. } \\
\text { Case series is at risk for more bias and relies heavily upon } \\
\text { accurate medical records and clear decision-making processes } \\
\text { noted in the record. } \\
\text { - There was no follow-up for the } 44 \text { dogs that had preoperative } \\
\text { signs of encephalopathy. } \\
\text { - Loss of data ( } 4 / 12 \text { dogs) in the follow-up period with the non- } \\
\text { encephalopathic dogs. } \\
\text { - The follow-up period for the non-encephalopathic dogs was } \\
\text { vague and did not indicate how many dogs made it to the } 10- \\
\text { year follow-up, or if most of the owners had only provided } \\
\text { short-term (1 year) follow-up data. Poor data provided about } \\
\text { the long-term prognosis. } \\
\text { - The owners did not report the presumptive cause of death in } \\
\text { their dogs. } \\
\text { Reliance on owners to report neurological signs for the follow- } \\
\text { up period increases risk of error because owners might miss } \\
\text { subtle neurological signs. }\end{array}$ \\
\hline
\end{tabular}

\begin{tabular}{|r|c|}
\hline Hunt \& Hughes (1999) & \multicolumn{2}{|c|}{ Population: } & $\begin{array}{l}\text { 49 dogs that underwent surgical attenuation using silk suture at the } \\
\text { Veterinary Cardiovascular Unit, Department of Veterinary Clinical } \\
\text { Sciences, The University of Sydney, Australia, between } 1989 \text { and } 1997 .\end{array}$ \\
\hline Sample size: & 49 dogs. \\
\hline Intervention details: & $-\quad \begin{array}{l}\text { Medical records were reviewed to identify dogs that } \\
\text { underwent surgical attenuation using silk suture for an } \\
\text { extrahepatic portosystemic shunt. } \\
\text { Surgical management of the congenital extrahepatic } \\
\text { portosystemic shunt with silk suture attenuation and complete } \\
\text { or partial ligation. }\end{array}$ \\
\hline
\end{tabular}




\begin{tabular}{|c|c|}
\hline Study design: & Single centre retrospective case series. \\
\hline Outcome studied: & $\begin{array}{l}\text { - Clinical signs and problems developed during the perioperative } \\
\text { (first } 24 \text { hours postoperatively), early postoperative ( } 24 \text { hours } \\
\text { postoperatively - skin suture removal) and long-term periods. } \\
\text { - Clinical efficacy of the primary surgeon ( } 38 \text { cases) compared to } \\
\text { one of six other surgeons. } \\
\text { - Degree of shunt attenuation. } \\
\text { - Portal pressure post-ligation. } \\
\text { Biochemical lab data obtained postoperative ( } 2 \text { weeks to } 6 \\
\text { years). }\end{array}$ \\
\hline $\begin{array}{l}\text { Main findings: } \\
\text { (relevant to PICO question): }\end{array}$ & $\begin{array}{l}\text { - } 48 / 49 \text { dogs survived to skin suture removal. } 1 / 49 \text { ( } 2 \% \text { ) mortality } \\
\text { rate. } \\
\text { - Five dogs experienced neurological abnormalities (seizures or } \\
\text { ataxia) suspected to be a manifestation of post-ligation seizure } \\
\text { syndrome } \\
\text { - } 9 / 49 \text { dogs ( } 18 \% \text { ) displayed neurological signs in the early } \\
\text { postoperative period, seven (14\%) of those were considered to } \\
\text { be related to the surgical attenuation, and two were due to } \\
\text { hypoglycaemia. Six were ataxic, two had generalised motor } \\
\text { seizures, one was disoriented and one had both ataxia and } \\
\text { muscle tremors. } \\
\text { - Three dogs that developed ataxia (without hypoglycaemia or } \\
\text { hyperammonemia) within } 1 \text { week of surgery resolved without } \\
\text { medical treatment. } \\
\text { - Two dogs with ataxia were hypoglycaemic and ataxia resolved } \\
\text { with glucose administration. } \\
\text { One of the dogs with seizures in the early postoperative period } \\
\text { was refractory to phenobarbital and died within } 24 \text { hours. } \\
\text { One dog developed ataxia, muscle tremors, and portal } \\
\text { hypertension leading to shunt ligature removal. } \\
\text { - } / 45 \text { dogs (20\%) had recurrence of hepatic encephalopathy } \\
\text { within } 18 \text { months postoperatively. One was due to } \\
\text { development of acquired shunts. In the others, patency of the } \\
\text { original shunting vessel was suspected. }\end{array}$ \\
\hline Limitations: & $\begin{array}{l}\text { - Reliance on owners to report neurological signs for the follow- } \\
\text { up period increases risk of error because owners might miss } \\
\text { subtle neurological signs. } \\
\text { Retrospective study is at risk for more bias than a prospective } \\
\text { study. } \\
\text { Case series is at risk for more bias and relies heavily upon } \\
\text { accurate medical records and clear decision-making processes } \\
\text { noted in the record. } \\
\text { - Difficult to differentiate in the perioperative period whether } \\
\text { the majority of the neurological signs in the dogs were } \\
\text { attributed to post-ligation neurological dysfunction or had } \\
\text { contributing components of hypoglycaemia and/or } \\
\text { hyperammonemia. } \\
\text { The follow-up with owners was relatively short-term to assess } \\
\text { continued neurological dysfunction. }\end{array}$ \\
\hline
\end{tabular}




\begin{tabular}{|c|c|}
\hline Population: & $\begin{array}{l}\text { Dogs that underwent surgical attenuation of a single congenital } \\
\text { extrahepatic portosystemic shunt (EHPSS) from January } 2005 \text { to July } \\
2017 \text { at } 10 \text { veterinary institutions and developed post-attenuation } \\
\text { seizures (PAS) within } 7 \text { days postoperatively. }\end{array}$ \\
\hline Sample size: & 940 dogs. \\
\hline Intervention details: & $\begin{array}{l}\text { - Medical records were reviewed to identify dogs that } \\
\text { underwent surgical attenuation of a single congenital EHPSS. } \\
\text { - Surgical management of congenital EHPSS with attenuation. } \\
\text { Dogs were divided into three groups. One group of } 523 \text { dogs } \\
\text { did not receive levetiracetam (LEV). The second group of } 188 \\
\text { dogs received LEV at a dose greater than } 15 \mathrm{mg} / \mathrm{kg} \text { every } 8 \\
\text { hours for more than } 24 \text { hours preoperatively or a } 60 \mathrm{mg} / \mathrm{kg} \text { IV } \\
\text { loading dose perioperatively with continuation of LEV } \\
\text { postoperatively at greater than } 15 \mathrm{mg} / \mathrm{kg} \text { every } 8 \text { hours. The } \\
\text { third group of } 229 \text { dogs received less than } 15 \mathrm{mg} / \mathrm{kg} \text { every } 8 \\
\text { hours for less than } 24 \text { hours preoperatively or LEV } \\
\text { postoperatively at less than } 15 \mathrm{mg} / \mathrm{kg} \text { every } 8 \text { hours. }\end{array}$ \\
\hline Study design: & Multi-centre retrospective cohort study. \\
\hline Outcome studied: & $\begin{array}{l}\text { - Development of PAS within } 7 \text { days postoperatively between the } \\
\text { three groups. } \\
\text { - Short term survival ( } 30 \text { days postoperatively) for the dogs that } \\
\text { developed PAS. }\end{array}$ \\
\hline $\begin{array}{l}\text { Main findings: } \\
\text { (relevant to PICO question): }\end{array}$ & $\begin{array}{l}\text { - } 75 / 940 \text { dogs ( } 7 \% \text { ) developed PAS within } 7 \text { days postoperatively. } \\
62 \text { had generalised PAS and } 13 \text { had focal PAS. Seizures onset at } \\
\text { a median of } 48 \text { hours (range } 8-128 \text { hours) postoperatively. } \\
\text { - } 61 / 75 \text { dogs ( } 81 \% \text { ) that developed PAS had preoperative } \\
\text { neurological signs including: lethargy, pacing/compulsive } \\
\text { walking, dullness, head pressing, ataxia, abnormal change in } \\
\text { behavior, hypersalivation/drooling, circling, etc. } \\
\text { - } 11 / 75 \text { dogs ( } 15 \% \text { ) that developed PAS had preoperative } \\
\text { seizures. } \\
\text { - } 35 / 75 \text { PAS dogs ( } 6 \text { were in the first group (6.7\%), } 21 \text { of the dogs } \\
\text { were in the second group ( } 11.2 \% \text { ), and } 19 \text { dogs were in the } \\
\text { third group ( } 8.3 \%) \text {. The difference between groups was not } \\
\text { significant ( }=0.14 \text { ). } \\
\text { - } 74 / 75 \text { PAS dogs received preoperative medical management } \\
\text { including a restricted protein diet, lactulose and antimicrobial } \\
\text { therapy. } \\
\text { - Ammonia and glucose concentrations were normal for the30 } \\
\text { and } 36 \text { PAS dogs, respectively. } \\
23 \text { of the } 75 \text { PAS dogs survived to } 30 \text { days postoperatively. }\end{array}$ \\
\hline Limitations: & $\begin{array}{l}\text { - Retrospective study is at risk for more bias than a prospective } \\
\text { study. } \\
\text { The } 75 \text { PAS dogs were reported to have received preoperative } \\
\text { medical management and it is unclear if this was continued } \\
\text { after surgery. Difficult to discern the impact of strictly surgical } \\
\text { intervention. } \\
\text { - Only had access to } 30 \text { and } 36 \text { of the } 75 \text { PAS dogs' serum } \\
\text { ammonia and glucose concentrations respectively, so }\end{array}$ \\
\hline
\end{tabular}




\begin{tabular}{|l|l|}
\hline & $\begin{array}{l}\text { neurological dysfunction caused by PAS and hepatic } \\
\text { encephalopathy cannot be differentiated. }\end{array}$ \\
- There was no follow-up of the dogs that did not display signs \\
of PAS within 7 days postoperatively. \\
There was no long-term follow-up of the PAS dogs.
\end{tabular}

\begin{tabular}{|c|c|}
\hline \multicolumn{2}{|l|}{ Strickland et al. (2018) } \\
\hline Population: & $\begin{array}{l}\text { Dogs that underwent partial or complete surgical attenuation of a } \\
\text { single congenital portosystemic shunt (CPSS) confirmed by a } \\
\text { mesenteric portovenogram at one institution between February } \\
2000 \text { and July } 2015 \text {. }\end{array}$ \\
\hline Sample size: & 253 dogs. \\
\hline Intervention details: & $\begin{array}{l}\text { - Medical records were reviewed to identify dogs that } \\
\text { underwent surgical attenuation of a single CPSS. } \\
196 \text { dogs had an extrahepatic shunt and } 57 \text { had an } \\
\text { intrahepatic shunt. } \\
\text { - Surgical management of CPSS. } \\
\text { - } 238 / 253 \text { dogs (94\%) received medical management prior to } \\
\text { surgery. } \\
\text { - Dogs with CPSS often display signs of hepatic } \\
\text { encephalopathy (HE), which may be linked to the } \\
\text { development of post-attenuation neurological signs (PANS), } \\
\text { a complication observed with surgical management of CPSS. }\end{array}$ \\
\hline Study design: & Single centre retrospective cohort study. \\
\hline Outcome studied: & $\begin{array}{l}\text { - Proportion of dogs that developed PANS. } \\
\text { - Proportion of dogs that had postoperative seizures. } \\
\text { - Proportion of dogs that had preoperative and postoperative } \\
\text { HE. } \\
\text { - Duration of clinical signs preoperative. } \\
\text { - Duration and response to medical management } \\
\text { preoperative. } \\
\text { Proportion of dogs with preoperative HE that developed } \\
\text { PANS. }\end{array}$ \\
\hline $\begin{array}{l}\text { Main findings: } \\
\text { (relevant to PICO question): }\end{array}$ & $\begin{array}{l}\text { - } 57 \text { days was the median duration of clinical signs of HE prior } \\
\text { to surgery. } \\
176 / 238 \text { dogs ( } 74 \%) \text { with HE preoperatively responded well } \\
\text { to medical management, } 49 / 238(21 \%) \text { responded } \\
\text { moderately, and } 13 / 238(5 \%) \text { responded poorly. } \\
\text { - } 23 / 196(12 \%) \text { dogs with an extrahepatic shunt developed } \\
\text { PANS. } \\
\text { - } 10 \text { dogs with an extrahepatic shunt had postoperative } \\
\text { seizures. } \\
\text { - } 22 / 28 \text { dogs ( } 79 \%) \text { that developed PANS had preoperative } \\
\text { signs of HE before surgery. } 9 / 28 \text { dogs ( } 32 \%) \text { had signs of HE } \\
\text { immediately before surgery. } 23 / 28 \text { dogs had an extrahepatic } \\
\text { shunt and } 5 / 28 \text { dogs had an intrahepatic shunt. } \\
\text { - Presence of HE preoperatively increased the odds of PANS } \\
2.704-\text { fold. }\end{array}$ \\
\hline
\end{tabular}




\begin{tabular}{|l|l|}
\hline & - There was no association between shunt location and \\
& incidence of PANS or seizures. \\
\hline Limitations: & $\begin{array}{l}\text { - Retrospective study is at risk for more bias than a } \\
\text { prospective study. }\end{array}$ \\
& $\begin{array}{l}\text { There was no long-term follow-up. } \\
\text { - The study did not separate intrahepatic and extrahepatic } \\
\text { preoperative HE and severity of PANS and seizures. }\end{array}$ \\
\hline
\end{tabular}

Tisdall et al. (2000)

\begin{tabular}{|c|c|}
\hline Population: & $\begin{array}{l}\text { Dogs with a congenital portosystemic shunt (CPSS) that presented to } \\
\text { the University Veterinary Centre, Sydney, Australia, between August } \\
1989 \text { and February } 1999 .\end{array}$ \\
\hline Sample size: & 121 dogs. \\
\hline Intervention details: & $\begin{array}{l}\text { - Medical records were reviewed to identify dogs with a CPSS. } \\
89 \text { dogs had extrahepatic shunts and } 32 \text { had intrahepatic } \\
\text { shunts. } \\
\text { - Surgical management of the extrahepatic shunts: } 12 \text { were } \\
\text { complete attenuation and } 77 \text { were partial attenuation. } \\
\text { - } 31 \text { dogs who had surgery after June } 1997 \text { received } \\
\text { prophylactic phenobarbital ( } 5-10 \mathrm{mg} / \mathrm{kg} \text { ) and for } 2 \text { weeks } \\
\text { (3-5 } \mathrm{mg} / \mathrm{kg} \text { q12) postoperatively. }\end{array}$ \\
\hline Study design: & Single centre retrospective cohort study. \\
\hline Outcome studied: & $\begin{array}{l}\text { - Neurological dysfunction of dogs with a congenital } \\
\text { extrahepatic shunt within } 7 \text { days postoperatively. } \\
\text { Serum phenobarbitone levels in dogs with a congenital } \\
\text { extrahepatic shunt treated prophylactically with } \\
\text { phenobarbitone. }\end{array}$ \\
\hline $\begin{array}{l}\text { Main findings: } \\
\text { (relevant to PICO question): }\end{array}$ & $\begin{array}{l}\text { - } 70 / 89 \text { dogs (79\%) displayed signs of hepatic encephalopathy } \\
\text { preoperatively. Seven of these dogs displayed neurological } \\
\text { dysfunction postoperative, and one had seizures } \\
\text { preoperative that did not resolve postoperative. } \\
11 / 89 \text { dogs (12\%) displayed neurological dysfunction within } \\
7 \text { days postoperatively. Three of these dogs did not display } \\
\text { neurological signs preoperatively. Nine of the dogs did not } \\
\text { receive phenobarbitone preoperatively. } \\
\text { - Three dogs developed seizures that lead to status } \\
\text { epilepticus and were initially refractory to therapy. One } \\
\text { succumbed to cardiac arrest. The other two responded to } \\
\text { thiopentone or pentobarbitone and were maintained on } \\
\text { phenobarbitone. } \\
\text { - Three dogs had nonprogressive ataxia which resolved } \\
\text { without treatment. } \\
\text { Three dogs had partial seizures with the reduction of } \\
\text { postoperative phenobarbitone doses. } \\
\text { Four dogs had severe neurological dysfunction, but no } \\
\text { seizures. Two were receiving phenobarbitone and } \\
\text { responded to additional phenobarbitone. The other two, } \\
\text { which had an abnormal anaesthetic recovery, responded to }\end{array}$ \\
\hline
\end{tabular}




\begin{tabular}{|l|l|}
\hline & $\begin{array}{l}\text { phenobarbitone and acepromazine. One resolved within } 72 \\
\text { hours. One was blind and ataxic at discharge } 15 \text { days } \\
\text { postoperatively and had a cellophane band placed } 8 \text { weeks } \\
\text { later which resolved the neurological signs but not the } \\
\text { blindness. One had residual hypermetria at discharge } 14 \\
\text { days postoperatively, which resolved in } 1 \text { week. One had } \\
\text { residual ataxia and central blindness } 14 \text { days } \\
\text { postoperatively, with the ataxia resolving } 4 \text { weeks } \\
\text { postoperatively and the blindness improving over } 2 \text { months. } \\
\text { None of the } 31 \text { dogs who received phenobarbitone } \\
\text { prophylactic had seizures, but two were ataxic. Serum } \\
\text { phenobarbitone levels were in therapeutic ranges for the } \\
\text { seven dogs assessed 3 days postoperatively. }\end{array}$ \\
\hline Limitations: & $\begin{array}{l}\text { This was a retrospective case series, which has a low level of } \\
\text { evidence and greater risk of bias than a prospective study. } \\
\text { Short follow-up period at seven days postoperatively. This } \\
\text { might not be reflective of the full risk and cases/signs that } \\
\text { developed or severely persisted past } 7 \text { days. } \\
\text { Small sample size. }\end{array}$ \\
\hline
\end{tabular}

Wallace et al. (2018)

\begin{tabular}{|c|c|}
\hline Population: & $\begin{array}{l}\text { Pugs undergoing surgical attenuation for a single congenital } \\
\text { extrahepatic portosystemic shunt (CEPSS) and had at least } 1 \text { month } \\
\text { of postoperative follow-up at Colorado State University Veterinary } \\
\text { Teaching Hospital, Colorado, USA, between } 1998 \text { and } 2010 \text {. Various } \\
\text { breed dogs (not Pugs) undergoing surgical attenuation for a single } \\
\text { CEPSS and had at least } 1 \text { month of postoperative follow-up at } \\
\text { Colorado State University Veterinary Teaching Hospital between } \\
1997 \text { and } 2005 \text {. }\end{array}$ \\
\hline Sample size: & 44 dogs. \\
\hline Intervention details: & $\begin{array}{l}\text { - Reviewed medical records to identify Pugs and control dogs } \\
\text { with a single CEPSS in the study. } \\
\text { - Surgical management of the single CEPSS. } \\
\text { - } 14 \text { Pugs were the study group and } 30 \text { other breeds of dogs } \\
\text { were in the control group. }\end{array}$ \\
\hline Study design: & Single centre retrospective cohort study. \\
\hline Outcome studied: & $\begin{array}{l}\text { - Preoperative information including the signalment and } \\
\text { clinicopathologic data. } \\
\text { - Postoperative neurological signs, specifically seizures. } \\
\text { - Postoperative mortality and complications. } \\
\text { - Bile acids measurement. } \\
\text { - Date and cause of death. }\end{array}$ \\
\hline $\begin{array}{l}\text { Main findings: } \\
\text { (relevant to PICO question): }\end{array}$ & $\begin{array}{l}\text { - 4/14 Pugs ( } 29 \%) \text { were euthanised within } 1 \text { month of surgery } \\
\text { from continued and/or worsening neurological signs. Two } \\
\text { were euthanised due to intractable seizures and two were } \\
\text { euthanised because of worsening and severe neurological } \\
\text { signs between } 2 \text { and } 29 \text { days postoperatively. There was no } \\
\text { evidence of necrotising meningoencephalitis. }\end{array}$ \\
\hline
\end{tabular}




\begin{tabular}{|c|c|}
\hline & $\begin{array}{l}\text { - One of the control group dogs died from intractable seizures } \\
\text { within } 1 \text { month postoperatively, which was significantly lower } \\
\text { mortality than the Pug group postoperatively. } \\
\text { - 6-72 month follow-up of } 9 / 10 \text { Pugs that survived. The owners } \\
\text { found no neurological signs or need for medical management. } \\
\text { - Bile acids were decreased postoperatively. }\end{array}$ \\
\hline Limitations: & $\begin{array}{l}\text { - The study is a retrospective study, which has more bias than a } \\
\text { prospective study and relies on very accurate medical records } \\
\text { and follow-up with owners. } \\
\text { - There was a loss of follow-up data with some of the Pugs } \\
\text { postoperatively. } \\
\text { - Small sample size. } \\
\text { - All the dogs in the study did not undergo the same surgical } \\
\text { procedure, most underwent cellophane banding, and one } \\
\text { underwent ameroid constrictor placement, which introduces } \\
\text { bias because one surgical methodology may be more effective } \\
\text { than the other. } \\
\text { Differences between the dates of study for the Pugs and } \\
\text { control group, as well as the significantly smaller average dog in } \\
\text { the control group compared to the Pugs. }\end{array}$ \\
\hline
\end{tabular}

\section{Watson \& Herrtage (1998)}

\begin{tabular}{|c|c|}
\hline Population: & $\begin{array}{l}\text { Dogs with a congenital portosystemic shunt (CPSS; confirmed by } \\
\text { ultrasound, contrast radiography, surgery or postmortem) and were } \\
\text { only managed medically that presented to the Department of Clinical } \\
\text { Veterinary Medicine (DCVM), University of Cambridge, UK, between } \\
\text { January } 1987 \text { and December } 1993 .\end{array}$ \\
\hline Sample size: & 27 dogs. \\
\hline Intervention details: & $\begin{array}{l}\text { - Case records were reviewed to identify eligible dogs for } \\
\text { inclusion in the study. Nine dogs had extrahepatic shunts, } 17 \\
\text { had intrahepatic shunts and one dog had a complex partially } \\
\text { intrahepatic and partially extrahepatic shunt. } \\
\text { Dogs were managed medically. } 23 \text { dogs were fed a reduced } \\
\text { protein diet (Canine u/d or kd/; Hill's Pet Products; homemade } \\
\text { or a combination). Two dogs were fed an unknown brand of } \\
\text { proprietary dog food with normal protein levels. Two dogs had } \\
\text { no diet recorded. } 24 \text { dogs received lactulose, consistently for } \\
18 / 24 \text { dogs ( } 75 \% \text { ) and at the start of treatment for } 6 / 24 \text { dogs } \\
\text { (25\%). } 2 / 27 \text { dogs ( } 7 \% \text { ) did not receive lactulose and } 1 / 27 \text { dogs } \\
\text { (4\%) had no record. Antibiotics were administered to } 24 / 27 \\
\text { dogs }(89 \%) .2 / 27 \text { dogs ( } 7 \% \text { ) did not receive antibiotics and } 1 / 27 \\
\text { dog ( }(4 \%) \text { had no record. }\end{array}$ \\
\hline Study design: & Single centre retrospective case series. \\
\hline Outcome studied: & $\begin{array}{l}\text { - Clinical signs, signalment, and blood work at initial } \\
\text { presentation. } \\
\text { - Change in clinical signs reported by owner after initiation of } \\
\text { medical management. } \\
\text { - Follow-up with owners } 3 \text { years after end of study for mortality } \\
\text { assessment. }\end{array}$ \\
\hline
\end{tabular}




\begin{tabular}{|c|c|}
\hline $\begin{array}{l}\text { Main findings: } \\
\text { (relevant to PICO question): }\end{array}$ & $\begin{array}{l}\text { - } 7 / 9 \text { dogs ( } 78 \% \text { ) with EHPSS had owner-reported neurological } \\
\text { signs (hyperactivity, depression head-pressing, circling, } \\
\text { excessive salivation, confusion, coma) prior to presentation. } \\
\text { Two dogs with EHPSS were lost to follow-up. } \\
\text { - } 1 / 7 \text { dogs ( } 14 \% \text { ) were reported by the owner to have } \\
\text { neurological signs more often after the start of medical } \\
\text { management. } \\
\text { - } 3 / 7 \text { dogs ( } 43 \% \text { ) were reported by the owners to have } \\
\text { neurological signs the same after the start of medical } \\
\text { management. } \\
\text { - } 3 / 7 \text { dogs ( } 43 \% \text { ) were reported by the owners to have } \\
\text { neurological signs less frequently after the start of medical } \\
\text { management. } \\
3 \text { years after study (October } 1996) \text {, three dogs with } \\
\text { extrahepatic shunts had been euthanised due to } \\
\text { uncontrollable neurological signs or ascites. } \\
\text { 3/9 dogs ( } 33 \% \text { ) with extrahepatic shunts were still alive } 3 \\
\text { years after the end of the study. }\end{array}$ \\
\hline Limitations: & $\begin{array}{l}\text { - Small sample size overall, but particularly for dogs with an } \\
\text { extrahepatic CPSS. } \\
\text { - Loss of information with owner follow-up, only able to } \\
\text { connect with } 14 \text { cases. } \\
\text { - Unclear how long initial follow-up was after initiating } \\
\text { medical management. } \\
\text { - } \text { medear which dogs received what components of the } \\
\text { dogs received none of the three. } \\
\text { - Subjective assessment in owner follow-up could lead to } \\
\text { increased risk of bias because not all owners interpret their } \\
\text { dog's change in clinical signs the same. The subjective } \\
\text { assessment also did not include severity of the clinical signs } \\
\text { noted. }\end{array}$ \\
\hline
\end{tabular}

\begin{tabular}{|c|c|}
\hline \multicolumn{2}{|l|}{ Worley \& Holt (2008) } \\
\hline Population: & $\begin{array}{l}\text { Dogs over five years old with a single congenital extrahepatic } \\
\text { portosystemic shunt (EHPSS) that underwent surgical attenuation } \\
\text { presenting at the University of Pennsylvania, USA, between } 1992 \\
\text { and } 2005 .\end{array}$ \\
\hline Sample size: & 17 dogs. \\
\hline Intervention details: & $\begin{array}{l}\text { - Medical records were reviewed to identify dogs eligible for } \\
\text { inclusion in the study. } \\
\text { - Surgical management of EHPSS: six dogs underwent } \\
\text { complete shunt ligation and } 11 \text { underwent partial shunt } \\
\text { attenuation. }\end{array}$ \\
\hline Study design: & Single centre retrospective case series. \\
\hline Outcome studied: & $\begin{array}{l}\text { - Preoperative data on the dogs were collected including } \\
\text { signalment, clinical signs, and clinicopathologic findings. } \\
\text { - Postoperative mortality rate and cause of death. }\end{array}$ \\
\hline
\end{tabular}




\begin{tabular}{|c|c|}
\hline & $\begin{array}{l}\text { Postoperative complications and clinical signs from } \\
\text { reevaluations and follow-up with owners and referring } \\
\text { veterinarians. } \\
\text { - Postoperative liver-function tests. }\end{array}$ \\
\hline $\begin{array}{l}\text { Main findings: } \\
\text { (relevant to PICO question): }\end{array}$ & $\begin{array}{l}\text { - } 12 / 17 \text { dogs (71\%) preoperatively displayed neurological } \\
\text { signs which could include abnormal mentation, ataxia, and } \\
\text { seizures. } \\
\text { - Immediate postoperative mortality rate was } 2 / 17 \text { dogs } \\
\text { (12\%). One dog with preoperative neurological signs } \\
\text { developed intractable seizures that were unresponsive to } \\
\text { multimodal drug therapy and was euthanised } 1 \text { week after } \\
\text { surgery. One dog went into cardiac arrest shortly after } \\
\text { surgery. } \\
\text { Three dogs with preoperative neurological signs developed } \\
\text { minor neurological signs post-surgery and two required } \\
\text { short-term therapy. } \\
\text { 4/17 dogs (24\%) displayed neurological signs } \\
\text { postoperatively. }\end{array}$ \\
\hline Limitations: & $\begin{array}{l}\text { - The study had a small sample size. } \\
\text { - This was a retrospective case series, which has a low level of } \\
\text { evidence and greater risk of bias than a prospective study. } \\
\text { - The study assumes that the record keeping was accurate. } \\
\text { - Postoperative data were collected through reevaluations } \\
\text { and telephone follow-up with owners and referring } \\
\text { veterinarians, which are subject to increased bias with two } \\
\text { of the } 15 \text { discharged dogs data lost to follow-up. }\end{array}$ \\
\hline
\end{tabular}

\section{Appraisal, application and reflection}

One of the most common clinical signs for a dog at presentation with an extrahepatic portosystemic shunt (EHPSS) is neurological signs, which can range in severity from mild head pressing and ataxia to seizures. The majority of EHPSSare managed through surgical attenuation, but that is not always an option for owners or achievable due to the anatomy of the shunt. Preoperative neurological signs of hepatic encephalopathy secondary to congenital extrahepatic portosystemic shunt (CEPSS) is caused predominantly by hyperammonemia, which decreases following successful shunt attenuation. The central nervous system may experience chronic astrocyte changes from a CEPSS, which causes an abnormal metabolic environment preoperatively and the sudden change of surgical attenuation favours an excitatory state. Post-attenuation neurological signs (PANS) is suspected to develop post attenuation when a metabolic event occurs in conjunction with the chronic preoperative central nervous system changes. Other contributing factors for dogs developing PANS is unknown, with conflicting evidence about the association of increasing age and shunt attenuation method. Unlike with hepatic encephalopathy, dogs that experience PANS have normal ammonia levels. There were no studies that had a direct comparison between the effectiveness of surgical or medical management of EHPSS in decreasing neurological signs. Overall, Strickland et al. (2018) found the lowest incidence of short-term postoperative neurological signs at 4/126 dogs (3\%), while Wallace et al. (2018) found the highest incidence of short-term postoperative neurological signs at $4 / 14$ dogs (29\%) and Watson \& Herrtage (1998) found an incidence of owner-reported decrease in neurological signs after the initiation of medical management of $3 / 7$ dogs $(43 \%)$, as well as a reported increase in quality of life.

Favier et al. (2020), Watson \& Herrtage (1998), and Strickland et al. (2018) found that the owners reported a decrease in neurological signs and an increase in quality of life after the initiation of medical management. However, these studies lost several dogs in the follow-up period and had relatively small sample sizes. Watson 
\& Herrtage (1998) also evaluated the long-term efficacy of medical management and at 3 years found that only $3 / 9$ dogs (33\%) of the dogs included in the follow-up were still alive.

All the studies that evaluated for surgical management found that there was an overall decrease in neurological signs from preoperatively to postoperatively. Worley \& Holt (2008) found that $12 / 17$ dogs (71\%) in their study displayed preoperative neurological signs, which decreased to $4 / 17$ dogs (24\%) after surgical attenuation. However, there was a risk of perioperative mortality or dogs succumbing to refractory seizures with 48 hours postoperatively. For instance, Tisdall et al. (2000) found that with surgical attenuation, the overall proportion of dogs with neurological signs decreased from 70/89 (79\%) preoperatively to 11/89 (12\%) postoperatively. The majority of the dogs with signs postoperatively had also displayed neurological signs prior to surgery. The study also found that there is a very weak association with the use of phenobarbital to decrease the incidence of postoperative seizures. Only two of the studies evaluated the longer-term efficacy of surgical attenuation in decreasing neurological signs associated with EHPSS. Wallace et al. (2018) had a followup ranging from 6 to 72 months postoperatively in nine Pugs with owners reporting no neurological signs or need for medical management. Harvey \& Erb (1998) had a 1-10 year follow-up period of eight of the 12 nonencephalopathic dogs, and owners reported the development of no neurological signs. However, both of the longer-term evaluations were based on owner reports, they were small sample sizes, and it is unclear how many dogs actually made it very far into the range of the follow-up period.

The studies suggest that there may be a weak association with higher mortality and/or increased severity of neurological signs that results in euthanasia in the immediate perioperative period for surgical management than after the initiation of medical management. For example, Fryer et al. (2011) had four dogs in the immediate postoperative period that had generalised motor seizures and did not survive to hospital discharge. Similarly, Wallace et al. (2018) found that four of the 14 Pugs were euthanised within 1 month of surgery from continued and/or worsening neurological signs and intractable seizures, and one of the control group dogs died from intractable seizures within 1 month postoperatively. However, although no immediate deaths were reported in either of the studies that addressed medical management, it cannot be ruled out because there is no clearly defined timeline for the dogs' deaths.

Two of the biggest limitations with these retrospective studies is that many only had very short-term follow-up periods and the data of several dogs were lost in the follow-up period. It was difficult to discern how a dog's quality of life might be impacted 5 years down the road after the initiation of medical management or postoperatively. Additionally, the owners were predominantly relied upon for accurate observation and reporting of neurological signs in their dogs. However, some neurological signs can be very subtle and might have been missed by the owner.

Further research should include prospective studies that have a clearly defined definition and inclusion criteria for post-attenuation neurological syndrome including blood ammonia and glucose levels postoperatively.

\section{Methodology}

\begin{tabular}{|c|c|}
\hline \multicolumn{2}{|l|}{ Search strategy } \\
\hline $\begin{array}{r}\text { Databases searched and dates } \\
\text { covered: }\end{array}$ & $\begin{array}{l}\text { CAB Abstracts on OVID Platform; January 1973-May } 2020 \\
\text { PubMed on NCBI Platform; January 1987-May } 2020\end{array}$ \\
\hline Search terms: & $\begin{array}{l}\text { CAB Abstracts: } \\
\text { (extrahepatic portosystemic shunt OR EHPSS OR CEPSS) AND (dog OR } \\
\text { canine) AND (neurologic OR neurological OR seizure OR hepatic } \\
\text { encephalopathy) } \\
\text { PubMed: } \\
\text { (congenital extrahepatic portosystemic shunt OR EHPSS OR CEPSS) AND } \\
\text { (dog OR canine) AND (neurologic OR neurological OR seizure OR hepatic } \\
\text { encephalopathy) }\end{array}$ \\
\hline Dates searches performed: & 28 Feb 2021 \\
\hline
\end{tabular}


Exclusion / Inclusion criteria

Exclusion: Book chapters, articles not available in English, clinical review articles, proceedings.

Inclusion: Articles available in English that were relevant to the PICO, articles had to involve more than five dogs.

\begin{tabular}{|l|c|c|c|c|c|c|}
\hline \multicolumn{1}{|c|}{ Search outcome } \\
\hline Database & $\begin{array}{c}\text { Number } \\
\text { of } \\
\text { results }\end{array}$ & $\begin{array}{r}\text { Excluded }- \\
\text { Clinical } \\
\text { review } \\
\text { article }\end{array}$ & $\begin{array}{c}\text { Excluded - } \\
\text { Not relevant } \\
\text { to PICO }\end{array}$ & $\begin{array}{r}\text { Excluded - } \\
\text { Case reports } \\
\text { with less than } \\
\text { five dogs }\end{array}$ & $\begin{array}{r}\text { Excluded - } \\
\text { Full article not } \\
\text { available }\end{array}$ & $\begin{array}{c}\text { Total } \\
\text { relevant } \\
\text { papers }\end{array}$ \\
\hline CAB & 8 & 0 & 5 & 1 & 0 & 2 \\
\hline Abstracts & 26 & 2 & 11 & 3 & 1 & 9 \\
\hline PubMed & 26 & & & 10 \\
\hline Total relevant papers when duplicates removed
\end{tabular}

\section{CONFLICT OF INTEREST}

The authors declare no conflict of interest.

\section{REFERENCES}

1. Favier, R.P., de Graaf, E., Corbee, R.J. \& Kummeling, A. (2020). Outcome of non-surgical dietary treatment with or without lactulose in dogs with congenital portosystemic shunts. The Veterianry Quarterly. 40(1), 108-114. DOI: https://doi.org/10.1080/01652176.2020.1745928

2. Fryer, K.J., Levine, J.M., Peycke, L.E., Thompson, J.A. \& Cohen, N.D. (2011). Incidence of postoperative seizures with and without levetiracetam pretreatment in dogs undergoing portosystemic shunt attenuation. Journal of Veterinary Internal Medicine. 25(6), 1379-1384.

DOI: https://doi.org/10.1111/j.1939-1676.2011.00819.x

3. Harvey, J. \& Erb, H.N. (1998). Complete ligation of extrahepatic congenital portosystemic shunts in nonencephalopathic dogs. Veterinary Surgery. 27(5), 413-416. DOI: https://doi.org/10.1111/i.1532950x.1998.tb00148.x

4. Hunt, G.B. \& Hughes, J. (1999). Outcomes after extrahepatic portosystemic shunt ligation in 49 dogs. Australian Veterinary Journal. 77(5), 303-307. DOI: https://doi.org/10.1111/i.17510813.1999.tb10268.x

5. Mullins, R.A., Sanchez Villamil, C., de Rooster, H., Kummeling, A., White, R.N., Thieman Mankin, K.M., Tivers, M.S., Yool, D.A., Anderson, D.M., Pratschke, K.M., Gordo, I., Brissot, H., Singh, A., Olive, M., Billet, J.P., Selmic, L.E. \& Kirby, B.M. (2019). Effect of prophylactic treatment with levetiracetam on the incidence of postattenuation seizures in dogs undergoing surgical management of single congenital extrahepatic portosystemic shunts. Veterinary Surgery. 48(2), 164-172.

DOI: https://doi.org/10.1111/vsu.13141 
6. Strickland, R., Tivers, M.S., Adamantos, S.E., Harcourt-Brown, T.R., Fowkes, R.C. \& Lipscomb, V.J. (2018). Incidence and risk factors for neurological signs after attenuation of single congenital portosystemic shunts in 253 dogs. Veterinary Surgery. 47(6), 745-755.

DOI: https://doi.org/10.1111/vsu.12925

7. Tisdall, P.L.C., Hunt, G.B., Youmans, K.R. \& Malik, R. (2000). Neurological dysfunction in dogs following attenuation of congenital extrahepatic portosystemic shunts. Journal of Small Animal Practice. 41(12), 539-546. DOI: https://doi.org/10.1111/i.1748-5827.2000.tb03150.x

8. Wallace, M.L., MacPhail, C.M. \& Monnet, E. (2018). Incidence of postoperative neurologic complications in Pugs following portosystemic shunt attenuation surgery. Journal of the American Animal Hospital Association. 54(1), 46-49. DOI: https://doi.org/10.5326/JAAHA-MS-6534

9. Watson, P.J. \& Herrtage, M.E. (1998). Medical management of congenital portosystemic shunts in 27 dogs - a retrospective study. Journal of Small Animal Practice. 39(2), 62-68.

DOI: https://doi.org/10.1111/j.1748-5827.1998.tb03595.x

10. Worley, D.R. \& Holt, D.E. (2008). Clinical outcome of congenital extrahepatic portosystemic shunt attenuation in dogs aged five years and older: 17 cases (1992-2005). Journal of the American Veterinary Medical Association. 232(5), 722-727. DOI: https://doi.org/10.2460/javma.232.5.722 


\section{EVIIDEFeE

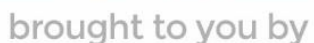 \\ RCVS KNOWLEDGE}

\section{Intellectual Property Rights}

Authors of Knowledge Summaries submitted to RCVS Knowledge for publication will retain copyright in their work, and will be required to grant RCVS Knowledge a non-exclusive license of the rights of copyright in the materials including but not limited to the right to publish, re-

publish, transmit, sell, distribute and otherwise use the materials in all languages and all media throughout the world, and to license or permit others to do so.

\section{Disclaimer}

Knowledge Summaries are a peer-reviewed article type which aims to answer a clinical question based on the best available current evidence. It does not override the responsibility

of the practitioner. Informed decisions should be made by considering such factors as individual clinical expertise and judgement along with patient's circumstances and owners' values. Knowledge Summaries are a resource to help inform and any opinions expressed within the Knowledge Summaries are the author's own and do not necessarily reflect the view of the RCVS Knowledge. Authors are responsible for the accuracy of the content. While the

Editor and Publisher believe that all content herein are in accord with current recommendations and practice at the time of publication, they accept no legal responsibility

for any errors or omissions, and make no warranty, express or implied, with respect to material contained within.

For further information please refer to our Terms of Use.

RCVS Knowledge is the independent charity associated with the Royal College of Veterinary Surgeons (RCVS). Our ambition is to become a global intermediary for evidence based veterinary knowledge by providing access to information

that is of immediate value to practicing veterinary professionals and directly contributes to evidence based clinical decision-making.

\section{https://www.veterinaryevidence.org/}

RCVS Knowledge is a registered Charity No. 230886.

Registered as a Company limited by guarantee in England and Wales No. 598443.

Registered Office: Belgravia House, 62-64 Horseferry Road, London SW1P 2AF

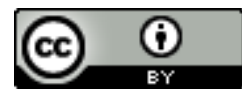

This work is licensed under a Creative Commons Attribution 4.0 International License. 